\title{
Portugal and the UN: \\ A Rogue State Resisting the Norm of \\ Decolonization (1956-1974)
}

\author{
Bruno Cardoso Reis
}

ICS-UL

This article looks at the Portuguese reaction to an increasingly numerous and hostile anti-colonial majority in the United Nations (UN), the central international norm-setting organization after 1945. More specifically I will focus on the persistence of a Portuguese policy of denying colonialism, that is, of formally declaring that Portugal was not a colonial empire but rather a unitary state with territories in different continents. Why would Portugal stick to this position for almost two decades, in the face of widespread scepticism and hostility from within a UN increasingly dominated by an anti-colonial stance - formally in the shape of General Assembly resolution 1542, of 1960 - that accused Portugal of being a colonial empire while refusing to accept this reality, and given the inevitable consequences of an emerging international norm of decolonization? ${ }^{1}$ Belgium also endured growing hostility at the UN for a long period. It faced a rising tide of anti-colonialism from 1946, as a founding member of the UN. In fact, even a speedy but messy decolonization of the Belgian Congo in 1960 did not put an end to criticism by the anti-colonial bloc at the UN of the neo-colonial relationship between Belgium and the Congo in general, and Katanga in particular, which presented a new target for criticism by the Afro-Asian bloc. This seems to indicate that confrontation of a state with the UN could be expected when there was a clash between normative change at the global level and core guidelines, 'constitutive' norms at the national level. ${ }^{2}$ This was the case regardless of regime type, authoritarian in the case of Portugal, parliamentary democracy in the case of Belgium. It also shows that a number of facilitating conditions were necessary in allowing prolonged resistance to international norms, of which two stand out:

\footnotetext{
The question of whether or not Portugal was a colonial empire is still a matter of some political controversy in Portugal. I follow a mainstream academic definition by Michael Doyle, Empires (Ithaca, NY: Cornell University Press, 1986): an empire exists whenever 'the effective sovereignty' of dependent peripheral territories is exercised by 'the dominant metropole' that 'exerts political control over the internal and external policy' of the former (p. 12).

2 Theo Farrell, Norms of War: Cultural Beliefs and Modern Conflict (Boulder, CO: Lynne Riener, 2005), pp. 8-9.
} 
(1) Minimal support to the rogue state by one or more of the five permanent members of the UN Security Council, ensuring that more damaging resolutions with mandatory sanctions were halted, softened or vetoed;

(2) Strongly nationalist domestic politics, so that losing votes at the UN would not weaken but, on the contrary, reinforce a preference for resistance to international norms.

But to pursue this analysis to its conclusions it is important, first, to look into the existing literature on the subject.

The question of the fight against the growing tide of anti-colonialism in the UN inevitably arises whenever the colonial policy of the Estado Novo is placed in an international context. ${ }^{3}$ It has been the main topic of a number of unpublished dissertations and articles, both in Portuguese and in English, that provide us with the basic outline of what happened during this period in terms of the confrontation of Portuguese diplomacy at the UN with the anti-colonial bloc. ${ }^{4}$ It makes no sense therefore to treat the subject as new ground and engage in a purely descriptive analysis. Even so, I will try to show that the earlier period, pre-entry and late 1950s are not as well known as the 1960s and 1970s, and there are some missing pieces that need to be fitted into the jigsaw.

It would be hard, moreover, to identify in the existing literature explicit debates or historical controversies. There seems to be a consensus that the UN became a major source of public attacks against the Portuguese regime and its policy of denying colonialism, and that this was reciprocated by the hostility towards, and disparaging views of, the UN on the part of the Estado Novo leadership. But what is not quite clear is the reason for the persistence of the Portuguese regime in its confrontation with the UN, or how to evaluate its results in comparative terms.

This topic deserves attention because decolonization changed global politics and the global balance of power - a point repeatedly made during these years

3 e.g. Pedro A. Oliveira, Os despojos da Aliança (Lisbon: Tinta da China, 2007); Fernando Martins, 'A questão colonial na política externa portuguesa: 1926-1975’, in O império africano (séculos XIX e XX), ed. by Valentim Alexandre (Lisbon: Edições Colibri, 200o ), pp. 137-65; António C. Pinto, 'Portugal e a resistência à descolonização', in História da expansão portuguesa, vol. v, ed. by F. Bethencourt and K. Chaudhuri (n.p.: Temas \& Debates, 200o), pp. 51-64; Norrie MacQueen, The Decolonization of Portuguese Africa: Metropolitan Revolution and the Dissolution of Empire (London: Longman, 1997), pp. 52-58 passim.

4 More specifically focused on the UN see e.g. A. E. Duarte Silva, 'O litígio entre Portugal e a ONU (1960-1974)', Análise Social, 30.130 (1995), 5-50; Fernando Martins, 'Portugal e a ONU: uma história da política externa e ultramarina portuguesa no pós-guerra, 1941-1968’ (unpublished MA dissertation, Lisbon, FCSH, 1996) and the article derived from the same, Idem, 'A política externa do Estado Novo, o Ultramar e a ONU, uma doutrina histórico-jurídica 1955-1968', Penélope, 18 (1996), 189-205. See also Denis C. Beller, 'The Portuguese Territories Issue in the UN: An Analysis of the Debates' (unpublished PhD dissertation, UCLA, 1970); Leah Fine, Colour-blind Colonialism? Lusotropicalismo and Portugal's 2oth Century Empire in Africa (unpublished MA dissertation, Barnard College, 2007); Norrie MacQueen, 'Belated Decolonization and UN Politics against the Backdrop of the Cold War: Portugal, Britain, and Guinea-Bissau's Proclamation of Independence, 1973-1974', Journal of Cold War Studies, 8.4 (2006), 29-56. 
by the Portuguese governing elite, which regretted the end of a Eurocentric international system. Decolonization ended the legitimacy of formal empires that had been an important feature of world politics for millennia. Yet decolonization as a world-historical event was incomplete while Portugal still held large territories overseas, resisting until 1974 this new UN-centred norm. It is worth analysing further why, for more than a decade, a small power like Portugal actively resisted the normative change leading to speedy decolonization, as supported by the two Cold War superpowers and many other countries.

In this article, my main aim is to deal with some key questions, namely:

- Why did Portugal apply for UN membership in 1945, and accept it in 1955?

- Why did Portugal remain in the UN, while increasingly facing pariah status as a result of resistance to the emerging anti-colonial norm, instead of either conforming or abandoning the organization?

- Were there different stages in this Portuguese diplomatic approach?

- How should we evaluate the success or failure of Portuguese diplomacy in the UN, particularly in comparison with a similarly small state like Belgium?

- What defines success for an authoritarian and nationalist regime like the Estado Novo in its dealings with the UN?

- What are the implications of this case for wider debates about the dynamics of the UN?

In addressing these questions the two initial sections of this article are more descriptive and are divided chronologically: first, an initial period of relative Portuguese success that was somewhat overshadowed by the problems that followed; second, a longer period of increasing crystallization of opposing views despite some occasional periods of détente as a result, for instance, of negotiations in the early 1960 os between Portugal and African states facilitated by the UN, or of expectations of change when Marcello Caetano replaced Salazar in 1968. A comparison of Portuguese and Belgian policy at the UN will follow. A final section will then try to say what drove Portugal to resist the emerging norm of rapid decolonization, as well as the wider significance of this in relation to ongoing debates about decolonization and about clashes over international normative change at the UN.

\section{UN Membership: Accession and Resistance (1945-1960)}

Why did Portugal become a member of the UN at all? (Switzerland refused this possibility until the end of the Cold War.) Why did the Portuguese regime choose to remain at the UN despite mounting criticism at that forum? This is all the more surprising given the often dismissive attitude of the leaders of the Estado Novo towards international organizations. 
Salazar, however - and this is an important point that seems to have been ignored by the existing historiography — did not always show contempt towards the UN. In a speech in May 1945, he signalled publicly his interest in the new international organization then being created. He stated that whilst 'Portugal is not among those that are now undertaking the delicate task of rebuilding the community of nations', it was 'a normal member of the international community' and, unlike Switzerland or the Vatican, its 'neutral status had ceased with the end of the war'. Salazar then went further and praised the efforts to design a new international organization. He did so, most significantly, not despite but precisely because of reports of a planned division of labour between a democratic General Assembly, in which the 'basis is the Nation' and member states were all 'sovereign and equal', and a Security Council, reserved only for a few great powers. To the founder of the authoritarian Estado Novo this seemed not only a necessary 'concession to the reality of international politics', but also, and more importantly, a recognition of 'an aristocratic principle in the effective direction of society'. Salazar's core belief in Realpolitik as well as in 'hierarchy' as the basis of politics, both foreign and domestic, is therefore made explicit. This is an important indicator of what would be Salazar's future approach towards the UN: a mixture of pragmatism in search of some great-power support and an elitist distancing from the will of the emerging non-Western majority. ${ }^{5}$ To persuade key countries to use, or at least threaten, a veto became the only realistic possibility for Portuguese diplomacy in the 1960 s to contain the impact of the anti-colonial majority at the UN General Assembly. But this was also an appropriate response according to the elitist Western-centric beliefs central to the political culture of the Estado Novo.

This positive perception of the UN by Salazar seemed out of character and soon proved so mistaken that it was forgotten by both his critics and his admirers alike. The power given to the permanent members of the Security Council meant that the USSR was able to veto Portuguese admittance for a decade. Also, starting as early as 1946, the General Assembly became a major forum for anti-colonialism. Salazar was not alone in failing to predict how quickly the UN - boosted by the strategic and ideological disputes of an emerging Cold War - would take on this role.

The main colonial powers, Britain in particular, had managed to guarantee that the only practical obligation of administering powers regarding their colonial territories under the charter of the UN was - according to Article 73 - to provide 'statistical and other information of a technical nature relating to economic, social, and educational conditions in the territories'. This was explicitly to be for 'information purposes' only, and any reporting would be 'subject to such limitation as security and constitutional considerations may require'. These tight formal guarantees seemed more than enough to justify the

5 A. Oliveira Salazar, speech 18 May 1945 in Salazar: pensamento e doutrina politica. Textos seleccionados, ed. by M. C. Henriques et al. (Lisbon: Verbo, 2007), p. 106. 
initial confidence of all colonial powers that they would have nothing to fear from the UN. The preeminent role of colonial statesmen in helping to shape this new organization - in particular from Britain and its dominions, men like General Smuts - could only have reinforced this. ${ }^{6}$ Therefore getting Portugal into the UN, without the UN interfering in national colonial policies, seemed a reasonable expectation in 1945 .

In 1946-47 anti-colonialism gained a growing influence in the General Assembly, where, by definition, colonial powers were a minority. Crucially, after 1945, this minority no longer included the leading global powers. Colonialism did not have the support of either of the two Cold War superpowers, which were instead interested in winning over to their side a majority of states - not least newly independent states - by all means possible. Portugal was aware of the problems created by this growing hostility from an increasing majority of states at the UN, not least because there was a tradition of diplomatic exchanges with other colonial powers, first and foremost with Britain, but also with Belgium and France. New post-1945 multilateral institutions, while increasingly creating difficulties for colonial powers, also provided new opportunities to exchange views, if only informally.

With regard to Portugal's membership of NATO, colonial powers sometimes converged to some extent, from 1949 onwards, in stressing the strategic importance of her overseas territories for Western security. There were also other less regular official discussions devoted specifically to colonial issues, including defence. The most regular and public of these meetings, regarding cooperation on technical issues in Africa, eventually led to the creation of the Combined Commission for Technical Co-operation in Africa south of the Sahara (CCTA) in 1950, officially as an organization devoted to the promotion of African development. In fact it had also been created by the colonial powers to try to ensure that the UN and its specialized agencies were kept out of development efforts in colonial Africa. ${ }^{8}$ All of this could not have failed to impress the Portuguese elite. It contributed to what turned out to be a misplaced confidence in the existence of a solid agreement among colonial powers to resist rapid decolonization in sub-Saharan Africa.

Furthermore, domestic politics made Portuguese admission to the UN desirable for the Estado Novo. Failure to get into the UN was being used by its political opponents as evidence that Salazar's authoritarianism had led to international isolation after 1945. Portuguese admittance to NATO had already made

6 Cf. Mark Mazower, No Enchanted Palace: The End of Empire and the Ideological Origins of the UN (Princeton, NJ: Princeton University Press, 2009), maxime p. 17.

7 See Christopher Coker, NATO, the Warsaw Pact, and Africa (Basingstoke: Macmillan, 1985); G. R. Berridge, South Africa, the Colonial Powers and African Defence: The Rise and Fall of the White Entente, 1948-60 (London: Macmillan, 1992).

8 References in Belgian documents are very clear in this regard, cf. e.g. AMAE, AF II, DG Politique, Section Aff. Coloniales, Note 1549 pour DGP ‘Sur l'activité de l'OIT en Afrique’ (6 March 1956); or Note Grojean for DGP on meeting Chargé Affaires Portugal Aragão (13 April 1956). 
that argument harder to sustain. But the fact that Portugal was finally admitted to the UN, on 14 December 1955, and its continued membership after that date, meant that the Portuguese state - regardless of the nature of the regime or the international criticism that it might attract — was recognized as a full member of the post-1945 international system. Admission to the UN could be and was portrayed by the Portuguese regime as a victory. True, Portugal was admitted as part of a 'package deal' with sixteen other new member states. But what mattered politically for Salazar and his regime was that this could be presented as proof that the US, which led the Western powers in supporting Portuguese membership, valued Portugal as an ally. ${ }^{9}$ Moreover, the linkage involved in the deal made it difficult for Portugal to refuse entry, because this might have jeopardized the whole deal and put the Western bloc at a disadvantage. ${ }^{10}$

A point that needs to be underlined, however, is that behind this wish to gain admittance to the UN there seems to have been another dimension, now forgotten, linked to the fight of the Estado Novo against decolonization. A member state of the UN had the automatic right to appeal to the International Court of Justice in a dispute with another member state. Portugal did this just one day after becoming a member of the UN - on 15 December 1955 asking the Court to rule against India and its policy of annexation of Goa and the other Portuguese enclaves in the Indian subcontinent. Dominated by law professors like Salazar, the Portuguese ruling elite was convinced that it could win the legal argument, and it did. This success could only have confirmed their already strong conviction of the appropriateness of a legalistic approach to the challenge of anti-colonialism. When this proved increasingly ineffective, the Portuguese elite attributed these set-backs to abusive re-interpretations or changes to existing international law. Portuguese entry into the UN system, ironically ended up being favourable to a reactionary retrenchment by the Portuguese regime into its core legalist argumentation for being an empire in denial. ${ }^{11}$

What do I mean by Portuguese colonialism in denial? In 1952 the Portuguese Constitution was amended to state that Portugal no longer had colonies; the territories concerned were now to be designated províncias ultramarinas [overseas provinces] and to be regarded as integral parts of a unitary pluricontinental state. This Portuguese constitutional amendment was, paradoxically or not, a revealing formal recognition of international normative change, particularly at the UN. This point was made by hard-line critics from within the regime, who saw even a purely formal concession to foreign pressure as

9 Cf. authorized biography of Salazar by his last foreign minister A. Franco Nogueira, Salazar. IV. O ataque (1945-1958) (Porto: Civilização, 1986), pp. 330, 389-90, 400.

10 Cf. Resolution 109 UN SC 14 December 1955 at <http://www.un.org/ga/search/view_doc. asp?symbol=S/RES/109 (1955) $>$ [accessed 14 March 2013]. Of the sixteen, only Portugal and Spain were firmly aligned with the West, the others were either neutral, like Austria or Finland, or more or less recently independent moderate countries like Jordan, Nepal, Cambodia, Laos or Libya.

11 Nogueira, Salazar. IV, pp. 400-01. 
unacceptable. ${ }^{12}$ Portuguese colonialism did not dare face this global normative change head-on; it had to deny its true nature. At the same time, of course (even if it is not possible to develop the theme here), the defenders of this change from colonies to overseas provinces could and did claim for it a Portuguese historical lineage. ${ }^{13}$

Based upon this constitutional change and using legal arguments, Salazar and his diplomats simply refused to conform to a norm that recent experience had shown to be the beginning of many difficulties for other colonial powers in the UN. In response to the usual letter from the Secretary General, in February 1956, asking Portugal for information about any dependent territories under Article 73 of the Charter, the Lisbon government simply answered that it had no non-self-governing territories. Constitutionally, Portugal was a single unitary state, albeit one spread across different continents. Should this interpretation be accepted, the regime was convinced that 'seria o colapso de toda a política de cerco do Ocidente' [it would put an end to the encirclement of the West] by the countries of the Afro-Asian Bloc which were 'desnorteados' [disorientated] and reacting with 'exaltação emotiva' [heightened emotions]. This was not, evidently, what then happened. Even discounting the rhetorical exaggeration of Franco Nogueira's language, he was right that what was at stake in this issue was ultimately how far the internationalization of the colonial question would go and whether Western states could put an end to the UN majority pressure on colonial issues or not. ${ }^{14}$

In the short term, for a few initial years, this strategy did seem to result in a measure of diplomatic success for Portugal. Her diplomats were also able to make a tactically clever use of UN procedural rules, for example regarding the requirement for a two-thirds majority for votes on important issues and the anti-colonial bloc had conceded this was such an issue by making repeated claims about the vital threat to global order that Portuguese denial of colonialism represented. This guaranteed a delay in any decision against Portugal because of lack of a sufficient anti-colonial majority in the General Assembly before 1960 .

Portuguese diplomacy realized it could not hope to get any significant support at the UN by fighting its case by an open advocacy of colonialism, nor were purely procedural tactics sufficient. Wisely, therefore, it supplemented its case by arguing the need to respect the norm of non-intervention in internal affairs in refusing any discussion of Portuguese constitutional matters, including its change of the status of overseas territories. Most states at the UN held this principle as an important normative shield against abusive foreign interventions by powerful states, and were careful not to erode it. In the initial

\footnotetext{
12 Armindo Monteiro former Minister of Colonies in the 1930s; cf. Pedro A. Oliveira, Armindo Monteiro: uma biografia politica (Lisbon: Bertrand Editora, 200o).

13 See Cláudia Castelo, 'O Modo Português de Estar no Mundo': o luso-tropicalismo e a ideologia colonial portuguesa (1933-1961) (Porto: Afrontamento, 1998).

14 Nogueira, Salazar. IV, p. 424.
} 
vote on the matter, in 1957, Portuguese diplomats achieved a draw - thirtyfive countries for the Portuguese position, with thirty-five countries against; five countries abstained and five were absent. These relatively positive results at the UN in the late 1950 s were also a result of the Portuguese government being able to use its remaining soft power to gather votes or abstentions from more conservative Latin American governments, in particular Brazil, as well as from NATO allies, using arguments of cultural identity and political solidarity. Only in 1959-60 did the growing anti-colonial majority in the UN manage to seriously challenge the Portuguese interpretation. But this was the high point of Portuguese diplomacy at the UN.

The tables were turned on Portugal in what was to be a defining moment in the normative history of decolonization. On the same day - 14 December 1960 - Resolution 1514 condemning colonialism in general was approved, alongside Resolution 1542 which explicitly rejected the Portuguese position as being one of colonialism in denial and in disguise. ${ }^{15}$

The formulation of the Portuguese answer to these new international challenges, and its persistent defence, was led by able professional diplomats like Franco Nogueira, with the help of other bright young legal minds including Adriano Moreira, a future overseas minister. Nogueira came more quickly and more enduringly into pre-eminence as a direct result of his leading role in the Portuguese delegations sent to the General Assembly after 1956, primarily with the mission of fighting anti-colonialism. He was appointed in rapid succession to increasingly important roles at the Portuguese Foreign Ministry: first, deputy director of political affairs in 1958, and full director in 1959; then director-general in 1960. Eventually, in 1961, he became Foreign Minister, a position he retained until $1969 .^{16}$

As regards the legal argument for the Portuguese case, it was published in book format in English as well as other foreign languages, in 1963, as part of a national and international campaign of public diplomacy led by Nogueira. The key point in the Portuguese argument was that, in re-interpreting Article 73, the UN General Assembly was violating the Charter and therefore resolutions such as 1542 had no legal value. Article 73 explicitly excluded constitutional matters. Portuguese delegates also argued that, more generically, Chapter XI was - unlike others - not titled 'international' by the Charter and this was why the General Assembly was not given explicit powers over colonial affairs, and was now illegally usurping them. But the main objection was, as pointed out, that Portuguese jurists strongly believed that the UN could not question or interpret the Portuguese Constitution as it stood when Portugal was accepted as a member of the UN - if the UN had any reservations about it, then it should

15 Belgium and France voted against this motion in support of Portugal, but Britain and the US abstained.

${ }_{16}$ Manuel de Lucena, 'A. M. G. Franco Nogueira', in Dicionário de História de Portugal. Suplemento, ed. by A. Barreto e M. F. Mónica (Porto: Figueirinhas, 1999), vol. viII, pp. 605-17. 
have made them at the time of accession, in December 1955. The anti-colonial offensive against the Portuguese regime was portrayed as a violation of key norms of the UN Charter, namely Article 2, regarding sovereign equality and non-intervention. The case presented by the Portuguese representatives went even further, accusing the General Assembly of violating the very universality of the rights and norms it claimed it was defending in arguing for the end of colonialism, by applying ethnicity and territorial discontinuity as a criterion for determining the absence of self-determination. Moreover, it disregarded the principle of equality, because not only Portugal but also other countries like the US in the case of Hawaii or Alaska - should be subject to it. This was presented by Portuguese decision-makers and diplomats as a form of 'racism in reverse', proof of an anti-White and an anti-Western prejudice held by a majority of the General Assembly. ${ }^{17}$

So why did Portugal not leave the UN at some point in the 196os? True, there was only one precedent for withdrawal, Indonesia in 1965, but that was only for a matter of months, and had not been a diplomatic success. The reasons are not difficult to deduce from what has previously been said about the Portuguese government wanting Portugal to become a member. Once Portugal had been admitted to the organization, the Portuguese regime could not easily leave without political loss of face, given the mounting international and internal criticism. Moreover, relinquishing any rights that they believed Portugal had was anathema to the highly nationalistic and authoritarian Estado Novo. Portugal had a right to be at the UN and, as far as the regime's elite was concerned, it had right on its side. Abandoning the organization would be to confess to a lack of either courage or strong arguments in defence of the cause of a Greater Portugal. This was unthinkable for the proudly nationalistic legal scholars that led the Portuguese regime.

\section{After 1960: The Struggle for Support in the UN}

The year 1960 was an important turning point in terms of decolonization, as no less than sixteen countries became independent in the African continent, the biggest and most sudden change in membership in UN history. It was a trend that was reinforced as more African countries gained independence during the years that followed. ${ }^{18}$

As regards the preferences of the Estado Novo's political culture, if it was acceptable to lose the support of the non-Western majority of the UN, it was very important to retain the support of at least some big Western powers, not only for pragmatic reasons, but also for normative reasons: after all, Portugal claimed it was defending Western civilization in Africa against Communism.

17 A. Franco Nogueira, The United Nations and Portugal: A Study in Anti-Colonialism (London: Sidgwick and Jackson, 1963).

${ }_{18}$ UN, 'Growth in UN Membership', in <http://www.un.org/en/members/growth.shtml> [accessed 16 February 2012]. 
The sudden shift, in 1960, in the balance of power in the UN General Assembly and its committees was all the more disappointing for the Portuguese governing elite, because it was in large part due to a sudden and unexpected shift in policy of the other major colonial powers resisting decolonization, France and Belgium. Indeed, until 1959 governments in Paris and Brussels as well as in Lisbon had converged in a determination to resist decolonization in the name of a shared belief in a necessarily slow pace for real overseas development, and a cultural and strategic preference for some kind of integration into a unitary state over full independence. As far as these three European powers were concerned, with the emergence of two superpowers, the US and the USSR, controlling vast territories and resources, the Cold War only made some kind of Eurafrica, i.e. a close association between European knowledge and African resources, all the more necessary. This may have been a product of the French 'official mind', but was eagerly adopted by Belgian and Portuguese officials also. ${ }^{19}$ The sudden change of direction towards rapid decolonization by France and Belgium was all the more unexpected because Portugal had been engaged, since 1957, in regular diplomatic quadripartite consultations with Belgium, Britain and France, with a strong focus on the UN. In fact, the Belgian elite was initially thinking more in terms of decades than years - much less one year when it publicly announced it had started considering devolution of power, in early 1959. Also the end-state was believed to be some kind of close association between Belgium and its Congo. ${ }^{20}$

In France, Michael Debré - who, as de Gaulle's Prime Minister, presided over the sudden acceleration of French decolonization, from a French Union, to a French Community, to Francophone independence - confessed this was the result of a number of improvisations, in particular in response to the frustration of pro-French African leaders at a status lower than full independence, making UN membership a prized outcome. ${ }^{21}$ The fact that Belgian and French decolonization suddenly and radically escaped the timetables and end-states established made the Portuguese ruling elite even more determined in its denial of colonialism and, therefore, its refusal to decolonize. It is facile but wrong to blame the Portuguese elite for being unable to foresee and anticipate what was in fact a sudden transformation, unexpected even for top Belgian and French decision-makers.

The end-result was, in any case, a very negative change for Portuguese policy at the UN. It was obvious then, even for the traditionally more accommodating British diplomacy, that this change would make the enlarged UN Committee on Decolonization 'an infernal nuisance' for colonial powers. ${ }^{22}$ Britain and

19 Guy Martin, 'Africa and the Ideology of Eurafrica: Neo-Colonialism or Pan-Africanism?', Journal of Modern African Studies, 20.2 (1982), 221-38.

${ }_{20}$ Cf. Jean Stengers, Congo: mythes et réalités (Brussels: Éds. Racine, 2007), maxime p. $271 \mathrm{ff}$.

${ }^{21}$ Michael Debré, Gouverner. 3. Mémoires 1958-1962 (Paris: Albin Michel, 1988), pp. 326-29.

22 Senior Colonial Office official Christopher Eastwood cit. in Wm. Roger Louis, 'Public Enemy Number One: Britain and the United Nations', in Ends of British Imperialism: The Scramble for Empire, Suez and Decolonization (London: I. B. Tauris, 2006), p. 702. 
Portugal were now the major remaining colonial powers. While British officials sometimes seriously considered abandoning the UN Committee on Decolonization, and eventually did so in 1971, the British government never seriously contemplated resisting the trend towards relatively rapid decolonization. Yet this was exactly what Portugal, a much smaller state, did: it retained all its overseas territories, making no gestures towards independence, while remaining in the UN. In doing so, Portugal became increasingly a rogue state, not only because of tensions with the Afro-Asian or Non-Aligned Bloc but also with some of its Western allies, particularly the US, the Nordic countries, and even Britain and the Netherlands.

The Portuguese Foreign Minister, on attending the first UN General Assembly in this new situation, in New York in October 1961, reported back to Salazar that 'os afro-asiáticos dominam inteiramente as N.U. [...] apoiados no grupo comunista. Dispondo de maioria automática de 60 votos em qualquer assunto' [the Afro-Asian [bloc] is entirely dominant at the UN [...] supported by the communist bloc, enjoying an automatic majority of 60 votes on any issue]. But to the Portuguese 'official mind' this was no reason to compromise with it. On the contrary, the feeling was of the need to resist what Nogueira perceived as 'o maior desplante' [the absolute contempt] of the new majority at the General Assembly for existing norms, 'declarando aberta e oficialmente que a Carta e o Regimento estão antiquados e não têm o menor interesse; a lei é a vontade da maioria; e assim respondem quando se lhes pergunta em que texto ou textos se baseia um qualquer proposta ou resolução' [declaring openly and formally that the Charter and the rules of procedure are out-dated and do not have the least importance; the law is the will of the majority; and this is their answer when they are asked on what text or texts any proposal or resolution is based]. ${ }^{23}$ For the conservative legalism that was a cornerstone of the political culture of the Estado Novo it was evident that traditional precedents and set procedure should prevail, not majority voting or progressive ideals. Therefore this great change at the UN invited more resistance, not appeasement by the Portuguese regime. ${ }^{24}$

Portugal became the prime target of anti-colonialism as the only state not willing to grant independence to overseas territories, with only openly racist Rhodesia and South Africa competing for attention. What mattered was that, regardless of their legal status in the Portuguese Constitution, these distant dependent territories were perceived as colonies by most other states, including traditional allies of Portugal. Not only that, but Portugal was willing to fight wars against decolonization in three of these territories, Angola from 1961, Guinea from 1963, and Mozambique in 1964.

The signs of this normative change, however, predated these armed conflicts and may have helped to spark them - in particular, General Assembly Reso-

\footnotetext{
23 ANTT - AOS/CD 8 Letter from Foreign Sec. Franco Nogueira to PM Salazar (New York, October 1961 [read 3 November 1961]).

24 'Resistance' was pointedly the title of the pertinent volume of the authorized biography of Salazar by Franco Nogueira, Salazar. V. A resistência (1958-1964) (Porto: Civilização, 1984).
} 
lution 1467 of December 1959 by which the Afro-Asian bloc finally managed to appoint a commission to interpret Portugal's position under Article 73. This in itself was a significant defeat of the procedural arguments being used by Portuguese diplomacy to block any such discussion. This was then followed by Resolution 1542, on 15 December 1960, that formally interpreted Article 73 of the Charter, specifically rejecting the 'Portuguese thesis' by stating that it was 'applicable to territories which were then' - i.e. at the time of the approval of the Charter in 1945 - 'known to be of the colonial type', making the 1952 Portuguese constitutional amendment irrelevant. It further stated that 'prima facie' it should be applied to any 'territory that is geographically separate and culturally and/or ethnically distinct from the country administering it'.

The increasing marginalization of Portugal at the UN culminated in a Security Council debate in November 1963, after Foreign Minister Franco Nogueira had gone through the motions of talking with a group of African countries, a move that had momentarily created great excitement and curiosity and even a more positive atmosphere in the General Assembly. But this was clearly not enough to change the Portuguese official mind. These were not true negotiations but more a typical diversionary measure by a rogue state, meant to deflect pressure from friendly governments. Nogueira made this more or less clear in informal consultations with the Brazilian and US representatives who had pressed for talks, and asked what Portugal had to offer: 'não faria nada' [would do nothing] or 'não sabia' [didn't know] were the answers. ${ }^{25}$ The US would later complain that 'Portugal does not negotiate, it does not talk'. Or as the US representative Adlai Stevenson put it, Portugal was 'diverting attention from more important matters' at the UN. Nogueira was not disarmed by this, simply asking whey they didn't change the subject. ${ }^{26}$ Of course, African states were equally unwilling to compromise their demands for total and rapid independence. ${ }^{27}$ The episode ended with the Security Council urging Portugal to conform to the General Assembly resolutions, and the Portuguese delegation reaffirming that it considered these new norms of decolonization illegal and void.

Was this merely talk? In my view this growing international attention at the UN was, in fact, an important factor in spurring the violent anti-colonial uprisings in Angola, in February and March 1961, which marked the beginning of the protracted guerrilla campaigns against Portuguese colonialism. Evidently the UN did not create the anti-colonial insurgency single-handedly or $a b$ initio, but it did provide an important initial spark. For these initially very weak insurgent movements, facing the full military and political might of the colonial state, it was very important to know that they had external support.

25 ANTT-AOS/CD 7 Letter Franco Nogueira to Salazar from New York (19 October 1963).

26 ANTT-AOS/CD 7 Letter Franco Nogueira to Salazar from New York (October 1963 [read 27 October 1963]).

27 ANTT-AOS/CD 7 Letter Franco Nogueira to Salazar from New York (October 1963 [read 27 October 1963]). 
Conversely, an armed uprising would evidently strengthen the hand of the countries arguing in the UN that Portugal ruled its African territories by force and not consent. A meeting of the Security Council was scheduled for 15 March 1961, the same day the UPA uprising started in northern Angola. ${ }^{28}$ Moreover, the founding leader of the UPA, Holden Roberto, who led the 1961 March uprising that started the war for the independence of Angola, had been invited to a public session of the General Assembly. In a key meeting, on 14 January 1961, in which the decision to begin the armed struggle was made, he claimed support from the 'soldados internacionais que nos ajudarão' [international forces who will help us] - an exaggerated claim, to say the least, but one made credible because of the on-going intervention, since July 1960, of 'blue helmets' in the former Belgian Congo where the meeting was taking place. According to Holden Roberto, Tunisian blue helmets in the Congo did provide some weapons to the insurgents.

Portuguese troubles at the UN were also not unconnected with the unprecedented pressure by the Kennedy Administration on Portugal to decolonize, to the point of supporting UPA insurgents in Angola as well as a failed Portuguese military pronunciamento against Salazar, in April 1961. The new US Administration was, initially at least, eager to use the UN to project the US as a leading progressive role-model for the post-colonial world. This is why, in the March 1961 meeting of the Security Council, the US voted in favour of the resolution put forward by Liberia, a close ally of Washington in Africa. It was only defeated because Portugal at that time could still secure six abstentions at the Security Council (Formosa, Chile, Ecuador, Britain, France, Turkey), depriving the US of the required majority. ${ }^{29}$

The year 1961 would end with a military intervention by India resulting in the forceful annexation of the Portuguese enclaves in the Indian subcontinent. True, this violence, like that in Angola, signalled, if not the failure, then certainly the limitations of what the Afro-Asian bloc, even a significant power like India, could achieve diplomatically at the UN in order to change the behaviour of the Portuguese regime. But the Indian military intervention, like the armed uprising in Angola, was also an indication that Portugal paid a price in other than diplomatic terms for its resistance to the norm of decolonization and its increasingly marginalized status on the international stage. Portugal could not find strong support even from its most powerful allies, like the US and Britain, who, while critical of the use of force by India, would do nothing to seriously damage their relations with New Delhi. It was, furthermore, the

\footnotetext{
28 Cit. in Dalila C. Mateus and A. Mateus, Angola 1961, Guerra colonial: causas e consequências. O 4 de Fevereiro e o 15 de Março (Alfragide: Texto, 2011), pp. 20, 140.

29 For the US position and the complex internal debates around it cf. José F. Antunes, Kennedye Salazar: o leão e a raposa (Lisbon: Difusão Cultural, 1992); Witney W. Schneidman. Engaging Africa: Washington and the Fall of Portugal's Colonial Empire (New York: University Press of America, 2004); Luís N. Rodrigues, Kennedy-Salazar: a crise de uma aliança. As relações luso-americanas entre $1961 e$ 1963 (Lisbon: Ed. Notícias, 2002).
} 
conviction of Portuguese intelligence and decision-makers that international pressure from the Afro-Asian Bloc had been decisive in persuading Nehru to approve a military option against the Portuguese in India. Still, Portuguese intransigence was credited by decision-makers in Lisbon with having caused some embarrassment to the credibility of both India and the UN, the former as an exemplary normative power, the latter as a normative shield against armed aggression. $^{30}$

Thereafter, even while denying its prestige, the notion that the UN was responsible for violence from abroad in Portuguese overseas territories became important in Portuguese official discourse. On 30 June 1961, Salazar chose to make the UN the key target of his first major speech reacting to the beginning of the anti-colonial uprising in Angola, significantly titled 'O ultramar português e a O.N.U.' [The Portuguese Overseas Territories and the UN]. He restated some key themes of the Portuguese position in the UN, including the fact that the organization should not 'be taken too seriously'. Salazar labelled the new Afro-Asian majority in the General Assembly a 'multidão tumultuária' i.e. a 'riotous mob', acting illegally against Portugal and inciting violence. What was really serious, however, was that the US, the main Western power, since March 1961 'resolvem apoiar ostensivamente o grupo afro-asiático, com o fim confessado de congregar votos fiéis em deliberações que interessem à América contra a Rússia [are resolved to support openly the Afro-Asian bloc, with the avowed aim of gathering loyal votes in [future] deliberations of interest to America against Russia] in the Cold War. This was all the more scandalous for Salazar, because he made a point of publicly stating that he had only sought admission to the UN 'at the request of Britain and the US arguing for the need to reinforce the Western bloc in case of any crisis.' Therefore, he denounced the Kennedy administration for shattering the unity of the West - something Salazar acknowledged with 'profunda mágoa' [deep sorrow] that he was also doing by this speech, but only because he had no alternative except to denounce a mistaken policy that was undermining Western security and values. US policy for Africa was now 'paralela à da Rússia' [parallel to that of Russia] and 'revela-se inconciliável' [is exposed as irreconcilable] with the Atlantic Alliance, because it ignored the fact that the USSR was engaged in a 'trabalho de subversão' [promotion of subversion] in the African continent in order to weaken Europe by breaking this vital strategic linkage in the context of the Cold War. ${ }^{31}$

These points, and in particular the linkage between African insurgencies and global 'communist threats' trying to 'infiltrar o Hemisfério Sul' [infiltrate the southern hemisphere] so as to outflank NATO, were to become a recurrent theme in Portuguese statements in NATO meetings, from the 1950 s until the

3o Cf. Maria J. Stocker, Xeque-Mate a Goa: o princípio do fim do império português, 2nd rev. edn (Alfragide: Texto, 2011), pp. $271 \mathrm{ff}$.

${ }^{31}$ A. Oliveira Salazar, O ultramar português e a O.N.U. Discurso proferido por Sua Excelência o Presidente do Conselho [...] na sessão extraordinária da Assembléia Nacional em 30 de junho de 1961 (Lisbon: SNI, 1961). 
very end of the regime, including the NATO summit held in 1971 in Lisbon, despite widespread international pressure for a boycott. ${ }^{32}$

Until 1963 Portugal maintained a relatively high profile in the UN; after that date the Portuguese Foreign Minister adopted a lower profile. For instance during a 'stormy' session in the Security Council, Nogueira opted to follow proceedings from the Portuguese delegation's office, in order to 'signal the little importance we attached to this noise', even as it was growing 'ever louder'. He was content to meet Secretary-General U Thant in private afterwards, 'and repudiate in toto the accusations of the Afro-Asians'. This became the usual pattern: a strict reaffirmation of the Portuguese case, and a denial of any facts allegedly showing that Portugal was provoking an inter-state conflict in Africa that might justify more forceful intervention or sanctions. Above all, Nogueira was now engaged in an exercise in diplomatic damage control through backdoor negotiations, using Western solidarity to 'chain-gang' allies and avoid a truly dangerous isolation. ${ }^{33}$

Particularly important in this context, evidently, was the position of the three Western permanent members of the Security Council - France, Britain and the US - not least because they could and did threaten to veto any resolutions that would increase the pressure on Portugal to a damaging extent. In the UN as well as NATO Portugal could usually count on support from France and Belgium, and more conditionally from Britain and the US from 1962 onwards, as well as from a few others. This is why we see Nogueira consulting with the French permanent representative in the UN and carefully reporting back to Salazar that France 'wished' to vote against any resolution targeting Portugal but that 'não pode ficar isolada' [it could not stand alone]. After all, Paris had given up its formal empire precisely to avoid isolation and maximize influence in Francophone Africa and the Third World, with great success, so the French diplomat claimed. He warned Portugal that it had to be careful with Britain and US. Nogueira concluded logically that this was 'uma notificação formal de que a França não usará do veto em nosso favor e nem sequer se absterá se os EU e a Inglaterra [sic] não se abstiverem também [a formal notification that France would not use its veto or even abstain if the US and England did not do the same]..$^{34}$

The official Portuguese perception of this period at the UN is made characteristically clear by Franco Nogueira in summarizing the state of affairs in 1966: 'não se eximem as Nações Unidas à aprovação das resoluções habituais

32 Quotation from last Foreign Minister of the regime, Rui Patrício (see note 53) [with Leonor Xavier], pp. 179-87. For the long-term view cf. António Telo, Portugal e a NATO: o reencontro da tradição atlântica (Lisbon: Cosmos, 1996), maxime pp. $290 \mathrm{ff}$.

33 A. Franco Nogueira, Um político confessa-se (Porto: Civilização, 1987), pp. 265-66. The concept of chain-ganging has become current in international relations to describe how a smaller power can use an alliance with a greater power to gain support from the latter. See Kenneth Waltz, Theory of International Politics (New York: McGraw-Hill, 1979), p. 167.

34 ANTT - AOS/CD 7, Letter Franco Nogueira to Salazar October 1963 [read 27 October 1963], heavily underlined. 
contra Portugal. Mas o facto de salientar é outro' [the UN does not refrain from approving the customary resolutions against Portugal. But that is not the important point]. The important point was that the US and a number of Western countries, including Brazil, voted against, and 'nenhum país da NATO ou latino-americano votou contra Portugal' [no NATO or Latin American country voted against Portugal]..$^{35}$

When Salazar was replaced in September 1968 by Marcello Caetano, little changed, despite internal and international expectations. An explicit condition of Caetano's appointment by the very conservative President of the Republic, Admiral Tomás, was an unconditional assurance by the former not to make any major changes in Portugal's position of retaining its overseas territories. ${ }^{36}$ To signal this internationally, Tomás also demanded that Salazar's last Foreign Minister, Nogueira, should remain in post for some time in the new government. ${ }^{37}$ When the latter left, after a year, Caetano made clear in his speech at the official appointment ceremony of the new Foreign Minister, Rui Patrício, that 'a prioridade número um' [his first priority] would be to 'zelar, explicar, defender a nossa política ultramarina' [take care of, explain, and defend our overseas policies]. Patrício states that he never received any other mandate during his four years in charge of Portuguese diplomacy: 'A orientação fundamental da nossa politica externa era a de não aceitar e evitar a internacionalização do problema ultramarino' [the fundamental guiding principle of our foreign policy was that of not accepting and of stopping the internationalization of the overseas problem]; it should be treated as an internal affair. He therefore had to resist UN attempts at intervention, and avoid 'o desmoronar de toda a construção politica e jurídica em que assentava a politica externa portuguesa' [the collapse of the whole political-juridical doctrine upon which Portuguese foreign policy rested]. ${ }^{38}$ This is a revealing formulation of the legalistic normative dogma dominating the Portuguese position at the UN.

The main novelty brought by Patrício, apart from his youth, was, he himself claims, that 'era menos arrogante e agressivo' [I was less arrogant, less aggressive] than his predecessor. Paradigmatic of this option was his decision to attend in person and speak publicly at the annual meeting of the UN General Assembly in 1972. This was clearly meant as an international test of the impact of the 1971 Constitutional Revision that gave Angola and Mozambique the official designation of states instead of overseas provinces, as part of a commitment to 'autonomia progressiva e participada' [progressive and participatory autonomy]. The UN majority saw this as too much legal formality and too little difference on the ground, especially because no clear signal of an acceptance of independence was forthcoming. Patrício's speech at the UN was

\footnotetext{
A. Franco Nogueira, Salazar. VI, p. 239.

Marcelo Caetano, Depoimento (Rio de Janeiro: Record, 1974), pp. 14-15.

Américo Thomaz, Últimas décadas de Portugal (Lisbon: Eds. FP, n.d.), p. 296 ff.

Cit. Rui Patrício, pp. 215-18.
} 
largely ignored, visibly so by many delegates who simply left the chamber when he started speaking, in a perfect illustration of Portugal's pariah status. ${ }^{39} \mathrm{In}$ fact, 1972 would see more aggressive UN resolutions against Portuguese colonialism, with the General Assembly declaring the anti-colonial insurgencies legitimate and recognizing the armed movements as sole representatives of the local populations. This extension of recognition and legitimacy 'until now only accorded to sovereign states' by the vast majority of the UN, excepting only a 'handful of international pariahs', part of the same club as Portugal, represents another important marker in a reversal of traditional international politics in which anti-colonial insurgents had been the pariahs, not the colonial states fighting them. The Algerian FLN had been probably the earliest example of this trend..$^{40}$ Even more important, the Security Council approved unanimously an appeal for a negotiated solution to the war that not even the US Nixon Administration felt it could vote against.

In 1973, there was further evidence that Portugal was increasingly a pariah for the majority of the UN. In September, the PAIGC had made a unilateral declaration of the independence of Guinea-Bissau. This was a major break from precedent in decolonization, and yet it was recognized by a majority of states. Its call for UN membership caused major embarrassment to Portugal, because even Western Cold War allies like Britain and the Netherlands were reluctant to appear too close to Portugal and its colonialism in denial. Still, as any pariah state must, Portugal did secure the support of at least one permanent member of the Security Council. The Nixon Administration guaranteed it would veto any decisive move of the UN in this respect. ${ }^{41}$

Patrício's final evaluation of this policy is predictably positive but in a significantly defensive and minimalist way: 'nenhum exército ameaçava [...] de invasão' [no army was threatening [the overseas territories] with invasion]. He also states that 'as deliberações da ONU, certamente cada vez mais ruidosas, continuavam tão ineficazes como dantes' [UN resolutions, though becoming ever more aggressive, were still as ineffective as before]. ${ }^{42}$ It was indeed the case that Portugal could still guarantee that at least one of the three Western powers with a veto in the UN Security Council 'frustrated the attempts of the [General] Assembly to engineer meaningful measures against' Portugal not only 'during the 1960s' but even in the 'early 1970s'. ${ }^{43}$ In this crucial respect Portuguese diplomacy in the UN was a Cold War success story, pushing for a minimal but vital support in defending the Estado Novo policy of colonialism in denial. In that sense, Cold War politics did trump UN politics. The strategic importance of Portugal in the Cold War - particularly of the US base in the Azores -

\footnotetext{
Rui Patrício, p. 150.

Matthew Connelly, A Diplomatic Revolution: Algeria's Fight for Independence and the Origins of the Post-Cold War Era (Oxford: Oxford University Press, 2002), p. 279.

${ }_{41}$ Norrie MacQueen, 'Belated Decolonization'.

42 Rui Patrício, p. 220.

43 Norrie MacQueen, 'Belated Decolonization', p. 56.
} 
could not make it any less of a pariah in terms of international society and its new standard norms of no colonial empires. But this global geopolitical dispute did give it the necessary room for manoeuvre in resisting UN pressure.

\section{The 'Portuguese thesis' and the 'Belgian thesis' in the UN}

Belgium, like Portugal, was a small power with a large overseas territory. Also, despite being a parliamentary democracy and not an authoritarian regime, Belgium like Portugal resisted for a long time the UN norm of speedy decolonization. This makes Belgium a good benchmark for evaluating the relative success of Portuguese diplomacy at the UN, especially if we take into account that because of a décalage in the timing of its admission Belgium went through many of the same problems of Portugal and faced similar pressures, but earlier. Since Belgium was a founding member of the UN and was much more deeply integrated into the new multilateral institutions it felt anti-colonial international pressure from 1946 onwards. Like Portugal, it took Belgium more than a decade of continued pressure at the UN for this to produce results; and arguably mainly not because of outside pressure per se, but also because of very rapid change in the dynamics among Congolese elites and a risk of violent confrontation on the ground.

It seems clear that the often mentioned Belgian-Congolese 'union' seemed more necessary than ever for Belgium immediately after 1945, for its economic recovery after the Second World War and as a source of strategic depth and strategic resources like uranium during the initial stages of the Cold War. But the importance of political culture should not be underestimated, with the Constitution revised, as in the case of Portugal, in 1952, to affirm this union, and King Baudouin of Belgium in a heavily publicized official visit to the Congo, in 1955, giving voice to this national consensus in talking of Congo and Belgium as 'one nation'. ${ }^{44}$ It should also be underlined that when rapid decolonization was accepted in 1959-60, this was not just because of international pressure or even fear of violence, but also because there was a strong, if quickly disproven, idea that a close association between Congo and Belgium could be preserved. ${ }^{45}$

It is crucial to note, therefore, how closely the Belgian official mind and its colonial discourse were aligned with those of Portuguese officials until the early 1960 s. Despite the differences in regime type there were clearly significant parallels in political culture in this close linkage between nationalism and colonialism that made decolonization a political taboo for a long time in both countries, despite growing international criticism. The response to pressure by the UN was also very similar, even if with the aforementioned décalage in timing. Belgium was subjected to the international pressure of anti-colonialism earlier. But it is very revealing that the complaints written in the late 1940 s by

44 Cit. and commented in Jean Stengers, Congo, pp. 245-46.

45 Jean Stengers, Congo, pp. 28o-81 passim. 
the Belgian Permanent Representative for Colonial Affairs at the UN could have been written by Portuguese diplomats a decade later. He denounced a 'generalized hostility to the colonial idea' leading to 'hasty voting of radical texts, clearly contrary to the Charter, sometimes even absurd'; he also complains that 'any negotiating is a fraud. What we accept as a maximum is definitively lost [...] but the adversary never gives up', and keeps demanding more concessions. The problem was that 'modest' demands in 1946 had already grown by 1947 to include 'information that was very clearly political', in violation of Article 73, and this trend was continued in 1948 and in 1949 and 'taken even further' in an unacceptable violation of the principle of non-interference in internal matters that 'constrains all organs of the UN'. ${ }^{46}$ These would be precisely some of the key arguments used by Portugal a decade later.

The official response by Belgium to this hostile internationalization of colonial issues at the UN came to be known as the 'Belgian thesis'. Again in parallel with Portugal, this was essentially a conservative legalistic response to a progressive political challenge. Belgian diplomats at the UN argued that many states in the world had native or minority populations that were not given full citizenship. Belgium therefore demanded that the UN should request and analyse information on all non-autonomous native populations, not just those who happened to live in colonies. The Belgian argument - again in close parallel with Portuguese arguments - tried to turn to its advantage the universalistic non-discriminatory normative outlook advocated by the majority of member states of the UN. ${ }^{47}$

The 'Belgian thesis' evidently contained important flaws and omissions e.g. no reference was made to racial inequality in terms of job opportunities, salaries, education, or political rights in the Congo. ${ }^{48}$ Yet it was based in arguments that were not entirely groundless, not necessarily because the native Congolese were living very well - that was certainly not the case compared with the Belgian settlers - but because they were living as well as, or often better than, many native populations in other parts of world, in situations that have come to be called internal colonialism.

The key aspect from the point of view of our analysis, however, is that the 'Belgian thesis' was a major diplomatic failure from the very beginning, in contrast with the 'Portuguese thesis' of 1956, of simply refusing any UN scrutiny. It met with total opposition by many member states whose support it needed - starting with major Western powers like the US, Australia and

\footnotetext{
46 Jacques Vanderlinden, Pierre Ryckmans 1891-1959: coloniser dans l'honneur (Brussels: De Boeck, 1994), p. 640. See also AMAE, Dossier XVIII 18875/ XXI, Statement by Belgium representative (M. de Bruyne) in UN GA (15 November 1949); and Letter from Belgium Perm. Rep. UN Langenhove to MAE Spaak (27 December 1949).

47 The official 'long version' intended as tool of public diplomacy was La Mission sacrée de Civilisation: à quelles populations faut-il en étendre le bénéfice? La Thèse Belge (New York: Belgian Government Information Center, 1953).

48 Stengers, Congo, p. $204 \mathrm{ff}$.
} 
many in central and south America that did not want to see their policies for their native populations or other minorities subject to international scrutiny. The 'Belgian thesis' was right on the facts - many native populations were living in terrible conditions in independent states - but inept in its diplomatic tactics. This disconnect was probably related to the fact that this 'Belgian thesis' was, nonetheless, widely praised internally in Belgium, since it allowed foreign criticisms of the Belgian model of colonialism to be presented as dishonest.

In contrast, the 'Portuguese thesis' of colonialism in denial was born, if not of a legal fiction, then certainly of a legal fiat, that is, the constitutional amendment of 1952. But fiction or not, this 'Portuguese thesis' did allow Portugal, unlike Belgium, to win enough votes, initially, to achieve positive diplomatic results. This was recognized by other colonial powers, including officials in Belgium and Britain. British officials in particular had been very sceptical about Portugal's diplomatic strategy of colonialism in denial, as well as about the ability of Portuguese diplomats to cope with the new challenges of conducting diplomacy in multilateral institutions. It is therefore significant that the British Colonial Office had to admit that the 'behaviour of the Portuguese [in the UN] so far has been eminently satisfactory'; and the Foreign Office agreed to admit Portugal into its annual consultations with Belgium and France about colonial affairs before the UN General Assembly, precisely because Portugal had 'shown up particularly well during their first session at the UN' in 1956. This contrasts with a deeply sceptical British view of the diplomatic usefulness for Belgium of the 'Belgian thesis', even if might be useful for Britain to have someone else raise this awkward subject of internal colonialism. ${ }^{49}$

Particularly significant for its colonial partners was the Portuguese ability to attract Latin American votes. The region had been a focus of interest and concern by other colonial powers, particularly Belgium, but without much success. ${ }^{50}$ Ironically, of course, it meant that this initial diplomatic victory for Portuguese colonialism in denial was rewarded by admittance to a closed diplomatic club of colonial powers, joining Britain, France and Belgium.

Success for the Portuguese regime at the UN, as with Belgium, does seem to have had some importance in domestic politics. In this context Portugal anticipated some of the strategies that have now become familiar of pariah regimes acting as spoilers of UN mainstream norms. Salazar, and his even more media-aware successor Marcello Caetano, ensured that Estado Novo propaganda took advantage of this hostile environment in the UN to spur nationalist sentiment and promote a rallying around the flag. This allowed the regime to denounce as treason any internal alignment with anti-colonial views.

It was in this context that Salazar coined the slogan 'combatemos [...] sem alianças, orgulhosamente sós' [we fight [...] without alliances, proudly alone].

49 TNA, CO 936/541 Letter from FO (JAH Watson] to CO (JE Marnham) (12 March 1957); and Letter IRD CO (JE Marnham) to FO (Robert Swann) (12 February 1956)

50 AMAE, AP I.I., Note DG Politique-Aff.Col. (16 October 1953) 'La Propagande Coloniale dans les Pays Anticolonialistes', pp. 13-17. 
It was a useful propaganda slogan for public consumption as Foreign Minister Franco Nogueira himself recognized.$^{51}$ Rui Patrício too states that only twice did he feel genuinely popular, once being when a speech of his in the UN General Assembly, in 1972, was met with such hostility that it provoked a nationalist response in Portugal, albeit orchestrated, especially in the sections of the press most closely controlled by the regime..$^{52}$ But evidently Portuguese diplomacy continued to work hard, often behind the scenes, to retain or regain foreign support from key Western powers, which supplied credit and vital military equipment, as well as some measure of support at the UN by vetoing resolutions, or more often using the threat of veto to moderate them, thereby shielding Portuguese colonialism in denial from tougher international action..$^{53}$

In following this path the Portuguese regime was drawing on a perception deeply rooted in Portuguese political culture, of Portugal as a small state, a brave pioneer of overseas expansion for the benefit of all, and of Western civilization in particular, that was being unfairly challenged by other states which deployed a variety of high-minded principles - freedom of the seas, freedom from slavery and forced labour, self-determination - as pretexts for depriving Portugal of its overseas territories. This was precisely the public position of Salazar, but it was also shared by his successor Marcello Caetano, who despite the fact that he was seen as the liberal face of the regime was in this crucial aspect representative of a wide consensus among the elites of the regime and even beyond, amongst more traditionalist leaders of the opposition. ${ }^{54}$

\section{Influence and Significance of the UN in Portuguese Decolonization}

What then is the significance of all this for the wider history of the UN and Portuguese decolonization during the period of the Cold War? I will emphasize five main points:

(1) The very existence of a Portuguese colonialism that was forced into denial of its true nature in official documents from 1952 onwards shows that the UN did have some influence, even if not in the most obvious way, since it was conditioned by Portuguese political culture and the perception of the national interest derived from it. Yet even when Portugal was still not a member of the organization, UN anti-colonialism was already driving the Estado Novo regime to adapt by redefining its colonies as overseas provinces the better to resist

\footnotetext{
51 A. Franco Nogueira, Salazar. VI. O último combate (1964-1970) (Porto: Civilização: 1985).

52 Rui Patrício [with Leonor Xavier], Rui Patrício: a vida conta-se inteira (n.p.: Temas \& Debates, 2010), p. 187. For a vivid testimony of how much attention was given to media management and public opinion, both foreign and domestic, in the final stage of the Portuguese dictatorship see the memoirs of another trusted former student of Caetano and his Director of National Information, Pedro Feyor Pinto, Na sombra do poder (Lisbon: D. Quixote, 2011), pp. $224 \mathrm{ff}$. passim.

53 Cf. e.g. Ana M. Fonseca, A força das armas: o apoio da República Federal da Alemanha ao Estado Novo (1958-1968) (Lisbon: Instituto Diplomático, 2007); Daniel S. C. Marcos, Salazar e de Gaulle: a França e a questão colonial portuguesa (1958-1968) (Lisbon: Instituto Diplomático, 2007).

54 Marcello Caetano, Portugal e a internacionalização dos problemas africanos (da liberdade dos mares à ONU) (Lisbon: Ática, 1962).
} 
the emerging international norm of speedy decolonization. The Portuguese regime did not clash head-on with the new norm, but tried to use a legalist way around it.

The less than obvious UN influence on Portugal did not end here. Perhaps the most effective and determined diplomatic enemy of the UN prodecolonization majority, Franco Nogueira, pointed (somewhat paradoxically) to his performance there: 'os grandes debates realizados no Conselho de Segurança da ONU representaram talvez do ponto de vista profissional, o momento mais alto da minha carreira' [the great debates that took place in the UN Security Council perhaps represented, in professional terms, the high point of my career]. ${ }^{55}$ More importantly even, he recognized that while the UN did not succeed during the Estado Novo in changing the content of a Portuguese foreign policy of colonialism in denial, it did change its style. The UN was an important school for Portuguese diplomats resulting in significant changes in skills required, making them adept not just at traditional 'entendimentos bilaterais' [bilateral agreements] but also at multilateral 'diplomacia da praça pública [public square diplomacy]. ${ }^{56}$ The skills developed in this losing battle to keep Portuguese overseas territories would eventually become important, ironically, after 1976, in the negotiations leading Portugal into accession to the EEC/EU or even, later, to prolonged multilateral diplomatic effort to free East Timor from Indonesian occupation.

(2) Portugal during these years illustrates some of the dynamics of so-called pariah or rogue states going against mainstream global norms, providing material for an objective analysis of this type of important phenomenon, then still very much in its infancy. ${ }^{57}$ But Portugal also shows the limitations of trying to ensure the prolonged and effective isolation of states which resist mainstream international norms. Resilient pariah states are successful in getting some support from key great powers, even within the UN system, for instance by their vetoing damaging sanctions, or threatening to do so. It is difficult to find a total pariah, in the sense of a truly isolated state. Even North Korea survives with support from at least one major power, namely China. Portugal was increasingly isolated in the UN - it was a pariah in that sense - but it could still rely on some vital support from within the Western bloc, particularly in the context of the global Cold War.

After some initial positive comments, quickly forgotten, Salazar repeatedly

55 Franco Nogueira with Maria J. Avillez 'Olhar para trás', Entre palavras 1974/1984 (Lisbon: Difel, 1984), p. 215.

56 A. Franco Nogueira, Salazar. IV. O Ataque (1945-1958), pp. 424-25.

57 Two pioneering works are Pascal Boniface, Guide du savoir nuire à l'usage des dictateurs (Paris: Éds. Michalon, 200o), who contrasts traditional puissance to nuisance; and Bruce Bueno de Mesquita and Alistair Johnson, The Dictator's Handbook: Why bad behavior is almost always good politics (New York: Public Affairs, 2011). I do not necessarily subscribe to their conclusions, but in different ways they try novel approaches to an issue that has not been sufficiently studied - rogue, marginal behaviour, trying to identify its logic. 
made clear that he believed the UN was worse than useless; it was positively dangerous. The case of the Indian invasion of Goa in 1961 was presented by him as proof that his scepticism was justified: the UN was unable and unwilling to stop military aggression. In this, Salazar was merely reflecting a common criticism of international organizations in the name of Realpolitik. Yet in dealing with an allegedly irrelevant institution the Portuguese government did spend a lot of political capital pressing other countries, especially key allies like the US, Britain and France, for support. For Salazar, the UN 'tem poder apenas mítico' [has only a mythical power], except for the one 'consentido pelas grandes potências' [consented by the great powers]. As a realist, Salazar did not believe that he should sacrifice 'interesses portugueses a título permanente' [Portuguese interests of a permanent nature] to norms being promoted by the UN, but for this resistance to succeed it was essential to make sure some of those major powers sided with Portugal..$^{5}$

(3) A global approach to the Cold War does help to explain some important features of this connection between the UN and Portuguese decolonization. Salazar perceived a national strategic need to keep vast overseas territories to maintain international relevance and independence. But he also saw this as convergent with Western strategic needs during the Cold War. True, American or British elites increasingly saw Portuguese colonialism in denial and the wars being fought to defend it from 1961 onwards as a problem for the Western bloc, not least in the UN. For Portuguese elites, however, Western Europe needed African strategic depth and resources to face a Soviet attack. To this was added, from 1967, with the closing of the Suez Canal by Nasser - a risk which Portuguese diplomacy had pointed up since 1956 - the argument of the strategic importance of Africa for trade and energy security in the Indian Ocean and the South Atlantic.

Portugal also insisted upon the importance of political solidarity as a public signal of the solidity of the Alliance, linking it with the credibility of the military deterrent of the Alliance, thereby constraining the full public expression of criticism, by the US and other key NATO allies, of Portuguese colonialism in denial. A further Cold War factor, not strategic but normative, limiting Western criticism of Portugal was that serious violations of human rights were also taking place in the Soviet Bloc, in Third World dictatorships, or even in the very intensive US counterinsurgency campaign in Vietnam. Finally, there was the strategic importance for the US military of their base in the Portuguese archipelago of the Azores for control of the North Atlantic and for effective projection of US military power into Europe and the Middle East.

As it had become clear to the US and other Western allies that Portugal would stick to its policy of colonialism in denial, these factors significantly limited

58 Cit. in A. Franco Nogueira, pp. 419-20; for a Realist sceptical vision of international organisations cf. J. Mearsheimer, 'The False Promise of International Institutions', International Security, 19.3 (1994-95), 5-49. 
how far the rest of the West would go in pressuring Portugal or in allowing the UN to do so. Furthermore, I argue for the need to pursue further a more global approach to the Cold War than one excessively centred on Washington and Moscow or even on a narrow understanding of Western Europe. The way the Portuguese empire ended had important implications in the following decade (1975-85), in undermining détente and exhausting the Soviet bloc in an overstretching of its economic and military resources in military aid to the periphery. ${ }^{59}$ But regardless of that more obvious impact, this article also shows that the perception of the Cold War by the Portuguese Estado Novo and other European governments was not necessarily coincident with that of the US; that is, they might give greater importance to the Third World than did the decision-makers in Washington.

These Cold War factors made Portugal sufficiently effective for most of this period at 'chain-ganging' the majority of its key Western allies, including the US, to at least some form of minimal support or limiting of criticism within the UN. This was made easier because of limited Portuguese exposure to US aid, loans or investment, when compared with other small European colonial powers; as well as by the Portuguese ability to secure alternative partners with similar views of the Cold War, in terms of financing, investment and economics, as well as acquisition of war material - France and Western Germany from the early 1960 s, and then later South Africa.

(4) In terms of the wider debates on the history of the UN, the comparison of the Portuguese and Belgian cases seem to vindicate Mark Mazower's key argument that the creation of the UN represented a triumph of the norm of sovereignty over minorities' rights that had been much more present in the League of Nations. ${ }^{60}$ Indeed, when Belgian officials tried to exploit the question of 'minorities' framed in terms of equal attention and scrutiny to the rights of native minorities by the UN in all states, and not just to natives in colonies, they got no diplomatic support for that position. By contrast, Portuguese diplomats had some initial success in exploiting diplomatically the question of non-interference in internal matters, playing on the fear of many states that the UN would erode their sovereign immunity. It is relevant to note that this rogue strategy has since become typical of pariah or spoiler states resisting mainstream UN norms.

That this worked for Portugal only for a limited period of time, however, also shows that between 1945 and 1960 sovereignty was being reshaped and re-used by the anti-colonial bloc against the existence of colonial dependencies in the name of the right to self-determination of sovereign peoples outside the West.

59 Cf. e.g. Tony Smith, 'New Bottles for New Wine: A Pericentric Framework for the Study of the Cold War', Diplomatic History, 24.4 (2000), 567-91; Odd Westad, The Global Cold War: Third World Interventions and the Making of Our Time (Cambridge: Cambridge University Press, 2005); Vladimir Shubin, The Hot 'Cold War': The USSR in Southern Africa (London: Pluto Press, 2008).

60 Mark Mazower, No Enchanted Palace, pp. 113, 195 passim. 
Before 1945, that is to say in the League of Nations, the limits of sovereignty were largely determined by Western imperial powers. Now, in the UN, this was being done against them. ${ }^{61}$ More specifically, the role of India as a normsetting entrepreneur challenging the doctrine of the European right to rule is confirmed by the Portuguese case. In fact, Portuguese sources explicitly validate it with the Portuguese Foreign Minister, for instance, expressing some interest that 'existem divergências graves' [there are serious disagreements] between Africans and Asians 'por cansaço da "tutela" indiana' [because of weariness at the Indian 'tutelage']. ${ }^{62}$

Portugal, on the other hand, and for two decades after entering the UN, in 1956, decided to stick to one of the original versions or visions of the UN that was by then looking increasingly outdated as the creation of Western sovereign states based on non-intervention in internal affairs. A very conservative and legalistic Portuguese political culture continued to perceive the West as intrinsically superior to the Rest, refusing to let go of the standard of civilization in its relations with other states or dependent territories. Defeats in votes at the UN could therefore be perceived as irrelevant because they were seen as the expression of the erroneous views or the prejudices of a growing but irrelevant number of non-Western countries. This was perceived not as an alarming sign of Portuguese isolation, but as an indication of the decadence of the UN, regarded as the vehicle of choice for inappropriate and even illegal expressions of anti-Western prejudices and interests, not as the promoter of new norms of political legitimacy.

(5) Lastly, political culture was a powerful foundation in building up resistance to foreign pressure, but it also proved to be a very serious if not insurmountable obstacle to any major change in policy to adapt to international normative change regarding colonialism. Empire was central to Portuguese nationalism and was therefore seen as a core element of Portuguese identity, formally expressed in the constitutional law of the regime, but also informally in the mass media and even in statements by significant opponents to Salazar and his regime. ${ }^{63}$ The strategy derived from this political culture in dealing with the UN made it, in turn, very difficult for Portugal to give ground, or to adopt a more flexible approach to decolonization, for instance by trying to negotiate different solutions for different territories. Why did Marcello Caetano inform

\footnotetext{
61 For this wider debate cf. Thomas Maddux et al. 'Mark Mazower. No Enchanted Palace...', H-Diplo Roundtable Reviews, 11.47 (2010), at <http://www.h-net.org/ diplo/roundtables/PDF/Roundtable-XI47.pdf> [accessed 11 October 2011].

62 Mazower, No Enchanted Palace, p. 153; ANTT - AOS/CD 8 Letter from Foreign Sec. Franco Nogueira to PM Salazar (New York, October 1961 [read 3 November 1961]).

63 Cf. on the traditional attachment to the colonies of the mainstream opposition to the regime of one of the key figures in decolonization in 1975, A. de Almeida Santos Quase memórias do colonialismo e descolonização (Cruz Quebrada: Casa das Letras, 2006), vol. I, p. 16; A. Costa Pinto, 'Nacionalismo', in Dicionário de História de Portugal. Suplemento, ed. by A. Barreto e M. F. Mónica (Porto: Figueirinhas, 1999), vol. viII, pp. 589-93.
} 
General Spínola that it was preferable to lose the war in Guinea than for Portugal to negotiate a way out in 1973 ? When he did so, he initiated the chain of events that led to the downfall of the authoritarian regime, because to do otherwise would mean violating the norm so vocally defended internationally, not least at the UN, that Portugal was a unitary pluri-continental state, and no parcel of it could be negotiated.

UN norms and political pressure in its institutions for speedy decolonization were neither immediately decisive nor irrelevant in Portuguese decolonization. Portuguese colonialism in denial in defiance of the new international norm of decolonization had political costs, but it also had significant human and material costs for Portugal, particularly in the form of protracted anti-colonial insurgencies. This was all the more significant because the conflict was made more prolonged and deadly by continued foreign support for the armed nationalist movements in Angola, Guinea and Mozambique, legitimized by the majority of the UN. Indirectly and in the medium term, therefore, the UN did play an important role in forcing major change that went against core beliefs in Portuguese political culture. Eventually, however, this would require a coup by the Portuguese military, exhausted by more than a decade of fighting. The state of internal flux in Portugal after regime change from April 1974 onwards made the UN norm of speedy decolonization much more difficult to resist at that moment. All of this provided a powerful boost to the coup leaders of the MFA Committee thanks to the impact of international pressure acting against the last-ditch attempts by General Spínola to achieve a controlled and relatively slow transfer of power, possibly ending in some form of close association with Portugal, at least in the case of Angola. Still, even in 1974-75, decolonization had to be made as acceptable as possible in terms of Portuguese political culture. The Portuguese military under the MFA was transformed into a 'fourth liberation movement'; a myth of decolonization transfigured what was arguably a Portuguese strategic defeat into a willing mutual liberation of the Portuguesespeaking world, which was presented by the new leftist governing elite in Lisbon as a liberated brotherhood. ${ }^{64}$

It was not just UN-led decolonization that showed the power of norms in international politics and security, however: it was also Portuguese resistance to it. It was not just the UN recurrent denunciation of Portuguese colonialism in denial that significantly conditioned the response of Portugal to decolonization. The Portuguese regime and its colonialism in denial also conditioned in an important way the calendar and the dynamics of UN formulation of norms for the final stage of decolonization.

64 A point first raised by Norrie MacQueen, The Decolonization of Portuguese Africa, pp. 80-84. 